\title{
Various levels of copra meal supplementation with $\beta$-Mannanase on growth performance, blood profile, nutrient digestibility, pork quality and economical analysis in growing-finishing pigs
}

\author{
H. J. Kim¹, S. O. Nam ${ }^{1}$, J. H. Jeong ${ }^{1}$, L. H. Fang ${ }^{1}$, H. B. Yoo ${ }^{1}$, S. H. Yoo ${ }^{1}$, J. S. Hong ${ }^{1}$, S. W. Son' ${ }^{2}$, S. H. Ha ${ }^{2}$
} and Y. Y. Kim ${ }^{1 *}$

\begin{abstract}
Background: To reduce use of main feed ingredient like corn, soy bean meal (SBM) and wheat, alternative ingredients has been studied like copra meal (CM). Production amount of CM which has been high makes CM to be an alternative feed stuff. However, low digestibility on AA and low energy content by high fiber content can be an obstacle for using $\mathrm{CM}$. This experiment was conducted to evaluate the effects of $\mathrm{CM}$ supplementation with $\beta$-mannanase on growth performance, blood profile, nutrient digestibility, pork quality and economic analysis in growing-finishing pigs.

Methods: A total of 100 growing pigs ([Yorkshire $\times$ Landrace] $\times$ Duroc) averaging $31.22 \pm 2.04 \mathrm{~kg}$ body weight were allotted to 5 different treatments by weight and sex in a randomized complete block (RCB) design in 5 replicate with 4 pigs per pen. Treatments were 1) Control (corn-SBM based diet $+0.1 \%$ of $\beta$-mannanase (800 IU)), 2) CM10 (10\% copra meal + 0.1\% $\beta$-mannanase (800 IU)), 3) CM15 (15\% copra meal + 0.1\% $\beta$-mannanase (800 IU)), 4) CM20 (20\% copra meal $+0.1 \% \beta$-mannanase (800 IU)) and 5) CM25 (25\% copra meal $+0.1 \% \beta$-mannanase (800 IU)). Four phase feeding program was used: growing I (week 1-3), growing II (week 4-6), finishing I (week 7-9) and finishing II (week 10-12).

Results: In growth performance, there was no significant difference among treatments during whole experimental period. In growingl phase, G.F ratio tended to increase when $C M$ was increased $(P=0.05)$, but $A D G$ and $A D F I$ tended to decrease in finishingll phase (linear, $P=0.08$ ). Also, increasing CM reduced ADG (linear, $P=0.02$ ) and feed efficiency (linear, $P=0.08$ ) during the whole finishing period. In blood profiles, BUN was linearly increased as CM increased (linear, $P=0.02)$ at growingll period. In digestibility trial, there was no significant difference in dry matter, crude fat, crude ash and nitrogen digestibility. However, crude protein digestibility was decreased linearly (linear, $P=0.02$ ). In economic analysis, feed cost per weight gain and total feed cost per pig were reduced in overall period when CM was provided by $25 \%$ (linear, $P=0.02$ ).
\end{abstract}

Conclusion: CM with $0.1 \%$ of $\beta$-mannanase ( $800 \mathrm{IU}$ ) could be supplemented instead of corn and SBM up to $25 \%$ without detrimental effects on growth performance and pork quality of growing-finishing pigs.

Keywords: Copra meal, $\beta$-mannanase, Growth performance, Economical analysis, Growing-finishing pigs

\footnotetext{
* Correspondence: yooykim@snu.ac.kr

${ }^{1}$ Department of Agricultural Biotechnology, College of Agriculture and Life Sciences, Seoul National University, 1 Gwanak-ro, Gwanak-gu, Seoul 08826, Republic of Korea

Full list of author information is available at the end of the article
} 


\section{Background}

Corn, SBM and wheat occupy the highest part of feed cost. To reduce the amount of those ingredients which were generally used in swine diet, various alternative ingredients such as palm kernel meal (PKM), CM, sorghum and others have been tested [1-3]. Those are needed to be an alternative feed ingredients which are sufficient production, stable supply, storage convenience and cheaper price than established ingredients [4]. CM fits to those required conditions and its production is currently emerging. There are more advantages in the amount of production and low price compared to corn or SBM as the by-product of oil extraction from coconut. CM has been extensively used in tropical regions that production amount is high enough to provide energy [5] or protein [6]. However, CM has disadvantages of low digestibility on essential amino acids [2] and low energy content [7] because of high dietary fiber (48.8\%, in DM; dry matter) [8].

These fiber sources in CM are mostly non-soluble dietary fiber (33.6\%, in DM) [8] and its main form is generally known mannose [9]. The mannose in CM has $\beta$-1,4-mannose chain structure and $\alpha$-1,6-galactose side chain $[10,11]$.

The great part of non-starch polysaccharides (NSP) in $\mathrm{CM}$ is mannan, and its proportion is $25 \sim 30 \%$ on a DM basis [9]. It suggests that the availability of the mannan can be improved with mannanase supplementation and consequently the range of usage for feed can be extended. Lee [12] demonstrated that 400 IU of $\beta$-mannanase supplementation to growing-finishing pigs tended to show the better growth performance, intestinal flora and nutrient digestibility in corn-SBM based diets. 800 IU level of $\beta$-mannanase was calculated by more amount of mannan substrate in CM. Based on these background, this experiment was conducted to evaluate effects of various level of CM with $\beta$-mannanase supplementation on growth performance, blood profile, nutrient digestibility, pork quality and economic analysis in growing-finishing pigs.

\section{Methods}

All experimental procedures involving animals were conducted in accordance with the Animal Experimental Guidelines provided by the Seoul National University Institutional Animal Care and Use Committee (SNUIACUC; SNU-160613-10).

\section{Animals and feeding trial}

A total of 100 crossbred pigs ([Yorkshire $\times$ Landrace] $\times$ Duroc) with an average body weight of $31.02 \pm 2.04 \mathrm{~kg}$ were used for 12 week feeding trial in experimental farm of Seoul National University. Pigs were grouped by body weight and sex, and assigned to five treatments according to RCB design. Each treatment had 5 replicates with 4 pigs per pen. Pigs were housed in growing pen $\left(1.40 \times 2.50 \mathrm{~m}^{2}\right)$ and finishing pen $\left(1.70 \times 2.50 \mathrm{~m}^{2}\right)$ that were easy to supply feed and water by ad libitum and control room temperature and ventilation. Body weight and feed intake were recorded at every 3 weeks to calculate the average daily gain (ADG), average daily feed intake (ADFI) and gain to feed ratio (G:F ratio) of the pigs.

\section{Experimental design and feeding program}

The treatments included 1) Control: $5 \%$ of copra meal + $0.1 \%$ of $\beta$-mannanase (800 IU), 2) CM10: $10 \%$ of copra meal $+0.1 \%$ of $\beta$-mannanase (800 IU), 3) CM15: $15 \%$ of copra meal $+0.1 \%$ of $\beta$-mannanase (800 IU), 4) CM20: $20 \%$ of copra meal $+0.1 \%$ of $\beta$-mannanase (800 IU), 5 ) CM25: $25 \%$ of copra meal $+0.1 \%$ of $\beta$-mannanase (800 IU). Mainly corn, SBM and wheat bran were replaced by the CM. The diets were formulated to contain 3,265 $\mathrm{kcal}$ of $\mathrm{ME} / \mathrm{kg}$ for the all phases. Experimental diets were mixed mainly with corn and SBM and nutrients of experimental diets were met or exceeded the requirement of NRC [13]. $\beta$-mannanase (patent, 10-04774560000; $\mathrm{CTCbio}^{\circ}$ Inc., Seoul, Republic of Korea) in dry form was supplemented in basal diet.

The feeding program was composed with four phases; growing I (week 1-3), growing II (week 4-6), finishing I (week 7-9) and finishing II (week 10-12) respectively. Formula and chemical composition of diet were presented in Tables 1, 2, 3 and 4. Expeller CM from Philippines was used in this experiment, and the analyzed composition was shown in Table 5 .

\section{Blood profiles}

Blood samples were collected from anterior vena cava of 6 pigs per each treatment at $0,3,6,9$ and 12 week for analyzing concentration of glucose and blood urea nitrogen (BUN) in serum. Collected blood samples were centrifuged for $15 \mathrm{~min}$ at 3,000 rpm in $4{ }^{\circ} \mathrm{C}$ (Eppendorf centrifuge 5810R, Germany). Serum was carefully removed to microtubes and stored at $-20{ }^{\circ} \mathrm{C}$ until analysis. Glucose and BUN concentration were analyzed using a blood analyzer (Ciba-Corning model, Express Plus, Ciba Corning Diagnostics Co.).

\section{Nutrient digestibility}

A total of 15 crossbred barrows, average body weight $34.73 \pm 0.24 \mathrm{~kg}$, were allocated to the each five treatment with three replicates in metabolic cages in a completely randomized design (CRD). The experimental diets were provided twice daily by $2.0 \%$ of body weight (on $1 \%$ of in each feeding) at 7:00 and 19:00, and water was provided by ad libitum. After 5 days of adaptation period, feces and urine were collected for further 5 days by the 
Table 1 Formula and chemical composition of the diet in growing phase I (0-3 week)

\begin{tabular}{|c|c|c|c|c|c|}
\hline \multirow[t]{2}{*}{ Criteria } & \multicolumn{5}{|c|}{ Treatment $^{\mathrm{a}}$} \\
\hline & Con & CM10 & CM15 & CM20 & CM25 \\
\hline \multicolumn{6}{|l|}{ Ingredient, \% } \\
\hline Corn & 54.65 & 53.23 & 51.82 & 50.37 & 48.94 \\
\hline SBM-45 & 25.07 & 23.41 & 21.79 & 20.09 & 18.47 \\
\hline Wheat bran & 9.88 & 7.96 & 5.99 & 4.17 & 2.23 \\
\hline Copra meal & 5.00 & 10.00 & 15.00 & 20.00 & 25.00 \\
\hline Soy oil & 2.76 & 2.76 & 2.76 & 2.76 & 2.76 \\
\hline DCP & 1.17 & 1.09 & 1.02 & 0.90 & 0.90 \\
\hline Limestone & 0.73 & 0.77 & 0.81 & 0.86 & 0.90 \\
\hline L-lysine $\mathrm{HCl}$ & 0.14 & 0.18 & 0.21 & 0.25 & 0.28 \\
\hline Vit. Mix ${ }^{b}$ & 0.10 & 0.10 & 0.10 & 0.10 & 0.10 \\
\hline Min. Mix & 0.10 & 0.10 & 0.10 & 0.10 & 0.10 \\
\hline Salt & 0.30 & 0.30 & 0.30 & 0.30 & 0.30 \\
\hline$\beta$-mannanase ${ }^{d}$ & 0.10 & 0.10 & 0.10 & 0.10 & 0.10 \\
\hline Total & 100.00 & 100.00 & 100.00 & 100.00 & 100.00 \\
\hline \multicolumn{6}{|c|}{ Chemical composition ${ }^{\mathrm{e}}$} \\
\hline $\mathrm{ME}, \mathrm{kcal} / \mathrm{kg}$ & $3,265.00$ & $3,265.01$ & $3,265.01$ & $3,265.00$ & $3,265.00$ \\
\hline$C P, \%$ & 18.00 & 18.00 & 18.00 & 18.00 & 18.00 \\
\hline Lysine, \% & 0.95 & 0.95 & 0.95 & 0.95 & 0.95 \\
\hline Methionine, \% & 0.26 & 0.26 & 0.26 & 0.27 & 0.27 \\
\hline $\mathrm{Ca}, \%$ & 0.60 & 0.60 & 0.60 & 0.60 & 0.60 \\
\hline Total P, \% & 0.50 & 0.50 & 0.50 & 0.50 & 0.50 \\
\hline \multicolumn{6}{|c|}{ 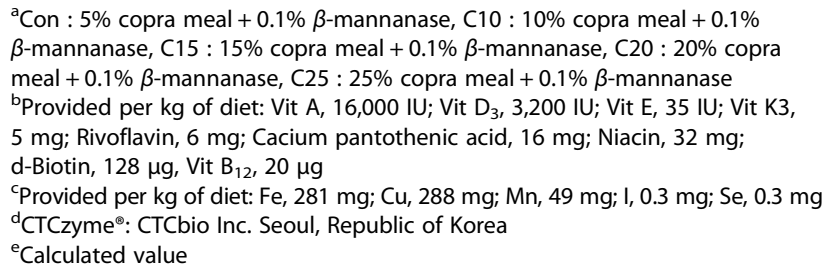 } \\
\hline
\end{tabular}

method of Hong et al. [14]. The feces and urine collected from each pig during these 5 days were stored at $-20{ }^{\circ} \mathrm{C}$ until they were analyzed. After collecting period, the excreta were dried in an air-forced drying oven at $60{ }^{\circ} \mathrm{C}$ for $72 \mathrm{~h}$ and ground to $2 \mathrm{~mm}$ of diameter by a Wiley mill for chemical analysis [15]. Feed, feces and urine were chemically analyzed by the method of AOAC [15].

\section{Carcass traits}

At the end of experiment, four pigs from each treatment group were selected and slaughtered at average $117.8 \pm 1.06 \mathrm{~kg}$ for the carcass analysis. Pork samples were collected from nearby 10th rib on right side of carcass. Because of chilling procedure, $30 \mathrm{~min}$ after slaughter was regarded as initial time. The $\mathrm{pH}$ and pork color were measured at $0,3,6,9,12$ and $24 \mathrm{~h}$, respectively. The $\mathrm{pH}$ was measured using a $\mathrm{pH}$ meter
Table 2 Formula and chemical composition of the diet in growing phase II (4-6 week)

\begin{tabular}{|c|c|c|c|c|c|}
\hline \multirow[t]{2}{*}{ Criteria } & \multicolumn{5}{|c|}{ Treatment $^{\mathrm{a}}$} \\
\hline & Con & CM10 & CM15 & CM20 & CM25 \\
\hline \multicolumn{6}{|l|}{ Ingredient, \% } \\
\hline Corn & 58.26 & 56.84 & 55.39 & 53.98 & 52.55 \\
\hline SBM-45 & 20.35 & 18.69 & 16.99 & 15.37 & 13.72 \\
\hline Wheat bran & 11.21 & 9.29 & 7.47 & 5.50 & 3.58 \\
\hline Copra meal & 5.00 & 10.00 & 15.00 & 20.00 & 25.00 \\
\hline Soy oil & 2.74 & 2.74 & 2.74 & 2.74 & 2.74 \\
\hline DCP & 1.11 & 1.02 & 0.92 & 0.81 & 0.77 \\
\hline Limestone & 0.63 & 0.68 & 0.71 & 0.79 & 0.79 \\
\hline L-lysine $\cdot \mathrm{HCl}$ & 0.10 & 0.14 & 0.18 & 0.21 & 0.25 \\
\hline Vit. Mix ${ }^{b}$ & 0.10 & 0.10 & 0.10 & 0.10 & 0.10 \\
\hline Min. Mix & 0.10 & 0.10 & 0.10 & 0.10 & 0.10 \\
\hline Salt & 0.30 & 0.30 & 0.30 & 0.30 & 0.30 \\
\hline$\beta$-mannanase ${ }^{d}$ & 0.10 & 0.10 & 0.10 & 0.10 & 0.10 \\
\hline Total & 100.00 & 100.00 & 100.00 & 100.00 & 100.00 \\
\hline \multicolumn{6}{|c|}{ Chemical composition ${ }^{\mathrm{e}}$} \\
\hline $\mathrm{ME}, \mathrm{kcal} / \mathrm{kg}$ & $3,265.00$ & $3,265.01$ & $3,265.01$ & $3,265.00$ & $3,265.00$ \\
\hline$C P, \%$ & 16.30 & 16.30 & 16.30 & 16.30 & 16.30 \\
\hline Lysine, \% & 0.82 & 0.82 & 0.82 & 0.82 & 0.82 \\
\hline Methionine, \% & 0.25 & 0.25 & 0.25 & 0.25 & 0.25 \\
\hline $\mathrm{Ca}, \%$ & 0.54 & 0.54 & 0.54 & 0.54 & 0.54 \\
\hline Total P, \% & 0.47 & 0.47 & 0.47 & 0.47 & 0.47 \\
\hline
\end{tabular}

${ }^{\mathrm{a}}$ Con : $5 \%$ copra meal $+0.1 \% \beta$-mannanase, $\mathrm{C} 10$ : $10 \%$ copra meal $+0.1 \%$ $\beta$-mannanase, C15 : $15 \%$ copra meal $+0.1 \% \beta$-mannanase, C20:20\% copra meal $+0.1 \% \beta$-mannanase, C25:25\% copra meal $+0.1 \% \beta$-mannanase

${ }^{\mathrm{b}}$ Provided per kg of diet: Vit A, 16,000 IU; Vit $\mathrm{D}_{3}, 3,200 \mathrm{IU}$; Vit E, 35 IU; Vit K3,

$5 \mathrm{mg}$; Rivoflavin, $6 \mathrm{mg}$; Cacium pantothenic acid, $16 \mathrm{mg}$; Niacin, $32 \mathrm{mg}$;

d-Biotin, $128 \mu \mathrm{g}$, Vit $\mathrm{B}_{12}, 20 \mu \mathrm{g}$

'Provided per kg of diet: Fe, $281 \mathrm{mg}$; Cu, $288 \mathrm{mg}$; Mn, 49 mg; l, $0.3 \mathrm{mg}$; Se, $0.3 \mathrm{mg}$ ${ }^{d}$ CTCzyme : CTCbio Inc. Seoul, Republic of Korea

${ }^{\mathrm{e}}$ Calculated value

(Bechman Coulter $\Phi 500$ Series, USA) and pork color was determined by CIE color $\mathrm{L}^{*}, \mathrm{a}^{*}$, and $\mathrm{b}^{*}$ values using a CR300 (Minolta Camera Co., Japan). Chemical analysis of pork samples were conducted by the method of AOAC [15].

\section{Pork quality}

Water holding capacity of pork was measured by centrifuge method (Ryoichi et al., 1993). Longissimus muscles were ground and sampled in filter tube, then heated in water bath at $80{ }^{\circ} \mathrm{C}$ for $20 \mathrm{~min}$ and centrifuged for $10 \mathrm{~min}$ at 2,000 rpm and $4{ }^{\circ} \mathrm{C}$ (Eppendorf centrifuge 5810R, Germany). After that, to calculate the cooking loss, longissimus muscles were packed with polyethylene bag and heated in water bath until core temperature reached $70{ }^{\circ} \mathrm{C}$ and weighed before and after cooking. After heated, samples were cored (0.5 in. in diameter) parallel to muscle fiber and the cores were used to 
Table 3 Formula and chemical composition of the diet in finishing phase I (7-9 week)

\begin{tabular}{|c|c|c|c|c|c|}
\hline \multirow[t]{2}{*}{ Criteria } & \multicolumn{5}{|c|}{ Treatment $^{a}$} \\
\hline & $\overline{C o n}$ & CM10 & CM15 & CM20 & CM25 \\
\hline \multicolumn{6}{|l|}{ Ingredient, \% } \\
\hline Corn & 59.93 & 58.50 & 57.06 & 55.67 & 54.24 \\
\hline SBM-45 & 18.10 & 16.43 & 14.77 & 13.15 & 11.50 \\
\hline Wheat bran & 11.96 & 10.09 & 8.20 & 6.20 & 4.28 \\
\hline Copra meal & 5.00 & 10.00 & 15.00 & 20.00 & 25.00 \\
\hline Soy oil & 2.72 & 2.72 & 2.72 & 2.72 & 2.72 \\
\hline DCP & 1.03 & 0.94 & 0.83 & 0.77 & 0.69 \\
\hline Limestone & 0.58 & 0.61 & 0.67 & 0.71 & 0.75 \\
\hline L-lysine $\mathrm{HCl}$ & 0.08 & 0.11 & 0.15 & 0.18 & 0.22 \\
\hline Vit. Mix ${ }^{b}$ & 0.10 & 0.10 & 0.10 & 0.10 & 0.10 \\
\hline Min. Mix & 0.10 & 0.10 & 0.10 & 0.10 & 0.10 \\
\hline Salt & 0.30 & 0.30 & 0.30 & 0.30 & 0.30 \\
\hline$\beta$-mannanase ${ }^{d}$ & 0.10 & 0.10 & 0.10 & 0.10 & 0.10 \\
\hline Total & 100.00 & 100.00 & 100.00 & 100.00 & 100.00 \\
\hline \multicolumn{6}{|c|}{ Chemical composition ${ }^{\mathrm{e}}$} \\
\hline $\mathrm{ME}, \mathrm{kcal} / \mathrm{kg}$ & $3,265.00$ & $3,265.00$ & $3,265.01$ & $3,265.01$ & $3,265.00$ \\
\hline $\mathrm{CP}, \%$ & 15.50 & 15.50 & 15.50 & 15.50 & 15.50 \\
\hline Lysine, \% & 0.75 & 0.75 & 0.75 & 0.75 & 0.75 \\
\hline Methionine, \% & 0.24 & 0.24 & 0.24 & 0.25 & 0.25 \\
\hline $\mathrm{Ca}, \%$ & 0.50 & 0.50 & 0.50 & 0.50 & 0.50 \\
\hline Total P, \% & 0.45 & 0.45 & 0.45 & 0.45 & 0.45 \\
\hline \multicolumn{6}{|c|}{ 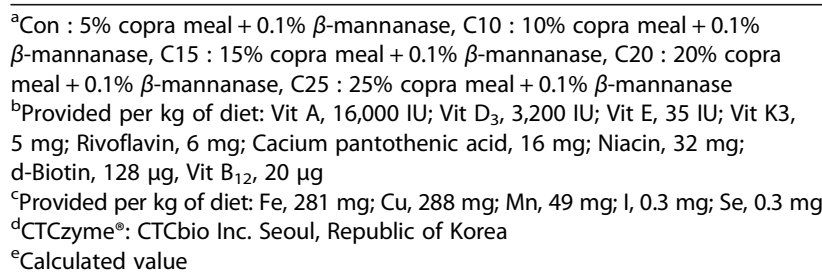 } \\
\hline
\end{tabular}

measure the shear force using a salter (Warner Bratzler Shear, USA). Shear force, cooking loss and water holding capacity of pork were analyzed by National Institute of Animal Science.

\section{Economic analysis}

As the experimental pigs were reared in the same environmental condition, economical efficiency was calculated by considering only the feed cost. The feed cost per body weight gain (won $/ \mathrm{kg}$ ) was calculated using total feed intake and feed price. The days to reaching market weight $(115 \mathrm{~kg})$ was estimated from the body weight at the end of feeding trial and ADG of 9-12 week.

\section{Statistical analysis}

All data were analyzed using the general linear model (GLM) procedure of SAS [16]. RCB design was adopted in feeding trial and pen was the experimental
Table 4 Formula and chemical composition of the diet in finishing phase II (10-12 week)

\begin{tabular}{|c|c|c|c|c|c|}
\hline \multirow[t]{2}{*}{ Criteria } & \multicolumn{5}{|c|}{ Treatment $^{a}$} \\
\hline & Con & CM10 & CM15 & CM20 & CM25 \\
\hline \multicolumn{6}{|l|}{ Ingredient, \% } \\
\hline Corn & 64.84 & 63.42 & 62.00 & 60.58 & 59.15 \\
\hline SBM-45 & 11.65 & 9.99 & 8.33 & 6.67 & 5.02 \\
\hline Wheat bran & 13.71 & 11.79 & 9.87 & 7.97 & 6.05 \\
\hline Copra meal & 5.00 & 10.00 & 15.00 & 20.00 & 25.00 \\
\hline Soy oil & 2.70 & 2.70 & 2.70 & 2.70 & 2.70 \\
\hline DCP & 0.85 & 0.78 & 0.70 & 0.61 & 0.52 \\
\hline Limestone & 0.59 & 0.62 & 0.66 & 0.70 & 0.75 \\
\hline L-lysine $\mathrm{HCl}$ & 0.06 & 0.10 & 0.14 & 0.17 & 0.21 \\
\hline Vit. Mix ${ }^{b}$ & 0.10 & 0.10 & 0.10 & 0.10 & 0.10 \\
\hline Min. Mix & 0.10 & 0.10 & 0.10 & 0.10 & 0.10 \\
\hline Salt & 0.30 & 0.30 & 0.30 & 0.30 & 0.30 \\
\hline$\beta$-mannanase ${ }^{d}$ & 0.10 & 0.10 & 0.10 & 0.10 & 0.10 \\
\hline Total & 100.00 & 100.00 & 100.00 & 100.00 & 100.00 \\
\hline \multicolumn{6}{|c|}{ Chemical composition ${ }^{\mathrm{e}}$} \\
\hline $\mathrm{ME}, \mathrm{kcal} / \mathrm{kg}$ & $3,265.00$ & $3,265.02$ & $3,265.04$ & $3,265.01$ & $3,265.00$ \\
\hline$C P, \%$ & 13.20 & 13.20 & 13.20 & 13.20 & 13.20 \\
\hline Lysine, \% & 0.60 & 0.60 & 0.60 & 0.60 & 0.60 \\
\hline Methionine, \% & 0.22 & 0.22 & 0.22 & 0.23 & 0.23 \\
\hline $\mathrm{Ca}, \%$ & 0.45 & 0.45 & 0.45 & 0.45 & 0.45 \\
\hline Total P, \% & 0.40 & 0.40 & 0.40 & 0.40 & 0.40 \\
\hline
\end{tabular}

${ }^{a}$ Con: $5 \%$ copra meal $+0.1 \% \beta$-mannanase, $\mathrm{C} 10: 10 \%$ copra meal $+0.1 \%$ $\beta$-mannanase, C15 : $15 \%$ copra meal $+0.1 \% \beta$-mannanase, C20 : 20\% copra meal $+0.1 \% \beta$-mannanase, C25:25\% copra meal $+0.1 \% \beta$-mannanase

${ }^{\mathrm{b}}$ Provided per kg of diet: Vit A, 16,000 IU; Vit $\mathrm{D}_{3}, 3,200 \mathrm{IU}$; Vit E, 35 IU; Vit K3, $5 \mathrm{mg}$; Rivoflavin, $6 \mathrm{mg}$; Cacium pantothenic acid, $16 \mathrm{mg}$; Niacin, $32 \mathrm{mg}$; d-Biotin, $128 \mu \mathrm{g}$, Vit $\mathrm{B}_{12}, 20 \mu \mathrm{g}$

'Provided per kg of diet: Fe, $281 \mathrm{mg}$; Cu, $288 \mathrm{mg}$; Mn, 49 mg; l, $0.3 \mathrm{mg}$; Se, $0.3 \mathrm{mg}$ ${ }^{\mathrm{d} C T C}$ Cyme ${ }^{\oplus}$ : CTCbio Inc. Seoul, Republic of Korea

${ }^{\mathrm{e}}$ Calculated value

block unit. CRD was adopted in digestibility trial, blood and carcass analysis and individual pig was the experimental unit. Statistical differences were considered significant at the level of $P<0.05$ and highly significant at the level of $P<0.01$, with a trend between $P \geq 0.05$ and $P \leq 0.10$ for Control group and $\mathrm{CM}$ treated group. Statistical differences were considered to be linear or quadratic at the level of $P<0.05$ and

Table 5 Analyzed composition of CM for experiment

\begin{tabular}{ll}
\hline Analyzed composition, \% & \\
\hline Crude protein & 19.50 \\
Ether extract & 07.35 \\
Moisture & 09.09 \\
Crude Ash & 05.94 \\
\hline
\end{tabular}


highly linear or quadratic at the level of $P<0.01$ for $\mathrm{CM}$ treated group.

\section{Results and Discussion Growth performance}

The effect of $\mathrm{CM}$ supplementation with $\beta$-mannanase on growth performance during 12 weeks was presented in Table 6. In growing phase, the level of $\mathrm{CM}$ did not affect the body weight (BW), ADG and ADFI. However, G:F ratio tended to increase when $C M$ level was increased in growing I phase (linear, $P=0.05$ ). In finishing I phase, tendency of quadratic response was observed on CM20 treatment (quadratic, $P=0.06$ ). During finishing
II period, the ADG and ADFI tended to decrease when $\mathrm{CM}$ level increased (linear, $P=0.08, \mathrm{P}=0.06$, respectively). Also, a linear response on the ADG (linear, $P=0.02$ ) and tendency of decreasing in $G: F$ ratio (linear, $P=0.08$ ) were observed as increasing level of $\mathrm{CM}$ in diet during the whole finishing period.

Nunes and Malmlof [17] reported that high level of mannan in swine diet interfered with the insulin and IGF-I secretion and affected negatively on growth performance. But, in current experiment, CM25 showed similar growth performance to CM5 without statistical difference in growing period and the whole experimental

Table 6 Effect of dietary levels of copra meal with $\beta$-mannanase on growth performance in growing-finishing pigs ${ }^{\mathrm{a}}$

\begin{tabular}{|c|c|c|c|c|c|c|c|c|}
\hline \multirow[t]{2}{*}{ Criteria } & \multicolumn{5}{|c|}{ Treatment } & \multirow[t]{2}{*}{$\mathrm{SEM}^{\mathrm{b}}$} & \multicolumn{2}{|c|}{$P$-value } \\
\hline & Con & CM10 & CM15 & CM20 & CM25 & & Lin. & Quad. \\
\hline \multicolumn{9}{|l|}{ Body weight, kg } \\
\hline Initial & 31.07 & 30.98 & 30.98 & 31.07 & 30.88 & 0.543 & - & - \\
\hline 3 week & 41.32 & 41.34 & 42.05 & 43.77 & 42.12 & 0.740 & 0.25 & 0.56 \\
\hline 6 week & 60.40 & 59.08 & 60.47 & 63.96 & 61.73 & 1.143 & 0.20 & 0.97 \\
\hline 9 week & 82.16 & 82.17 & 83.22 & 85.94 & 83.17 & 1.264 & 0.33 & 0.57 \\
\hline 12 week & 101.77 & 101.93 & 99.95 & 101.98 & 99.91 & 1.172 & 0.61 & 0.96 \\
\hline \multicolumn{9}{|l|}{$A D G, g$} \\
\hline 0-3 week & 488 & 493 & 532 & 606 & 524 & 19.9 & 0.25 & 0.46 \\
\hline 4-6 week & 909 & 845 & 877 & 962 & 934 & 25.8 & 0.34 & 0.54 \\
\hline 7-9 week & 1,036 & 1,099 & 1,083 & 1,047 & 1,020 & 16.9 & 0.49 & 0.19 \\
\hline 10-12 week & 934 & 941 & 797 & 764 & 797 & 36.1 & 0.08 & 0.56 \\
\hline 0-6 week & 698 & 669 & 704 & 784 & 729 & 19.0 & 0.19 & 0.96 \\
\hline 7-12 week & 985 & 1,020 & 940 & 905 & 909 & 17.1 & 0.02 & 0.87 \\
\hline 0-12 week & 842 & 844 & 822 & 845 & 819 & 9.8 & 0.57 & 0.89 \\
\hline \multicolumn{9}{|l|}{ ADFI, g } \\
\hline 0-3 week & 1,557 & 1,464 & 1,415 & 1,596 & 1,406 & 47.0 & 0.63 & 0.93 \\
\hline 4-6 week & 2,143 & 2,051 & 2,124 & 2,129 & 2,177 & 56.8 & 0.73 & 0.66 \\
\hline 7-9 week & 2,969 & 3,024 & 2,894 & 3,037 & 3,291 & 62.4 & 0.12 & 0.17 \\
\hline 10-12 week & 3,077 & 3,060 & 2,782 & 2,863 & 2,602 & 74.4 & 0.06 & 0.84 \\
\hline 0-6 week & 1,850 & 1,758 & 1,769 & 1,862 & 1,791 & 45.8 & 0.97 & 0.75 \\
\hline 7-12 week & 3,023 & 3,042 & 2,838 & 2,950 & 2,947 & 49.0 & 0.55 & 0.57 \\
\hline 0-12 week & 2,437 & 2,400 & 2,303 & 2,406 & 2,369 & 43.3 & 0.70 & 0.62 \\
\hline \multicolumn{9}{|l|}{ G:F ratio } \\
\hline 0-3 week & 0.310 & 0.340 & 0.378 & 0.383 & 0.373 & 0.0113 & 0.05 & 0.24 \\
\hline 4-6 week & 0.423 & 0.411 & 0.412 & 0.461 & 0.433 & 0.0119 & 0.51 & 0.88 \\
\hline 7-9 week & 0.350 & 0.363 & 0.376 & 0.346 & 0.311 & 0.0082 & 0.11 & 0.05 \\
\hline 10-12 week & 0.304 & 0.310 & 0.282 & 0.269 & 0.308 & 0.0108 & 0.67 & 0.40 \\
\hline 0-6 week & 0.376 & 0.381 & 0.398 & 0.427 & 0.408 & 0.0083 & 0.11 & 0.63 \\
\hline 7-12 week & 0.327 & 0.336 & 0.331 & 0.308 & 0.309 & 0.0057 & 0.08 & 0.39 \\
\hline 0-12 week & 0.346 & 0.353 & 0.357 & 0.353 & 0.346 & 0.0038 & 0.97 & 0.28 \\
\hline
\end{tabular}

${ }^{\mathrm{a} A}$ total of 100 crossbred pigs was fed from average initial body weight $31.02 \pm 2.04 \mathrm{~kg}$ to average final body weight $100.17 \mathrm{~kg}$ 
period. This can be explained by result of Khanongnuch et al. [18] that exogenous mannanase which degraded mannan in CM was sufficient even in CM25, so that they had enough transit time to digest ingesta including CM. Petty et al. [19] also reported adding $\beta$-mannanase to diets had a positive influence on pigs and improved the G:F ratio $(P<0.01)$.

Similarly, supplementation of mannan degrading enzyme to growing-finishing pig diet has increased G:F ratio and lean gain $[20,21]$. However, in finishing II phase and during whole finishing period, ADFI was decreased in agreement with Jaworski et al. [22] who demonstrated that supplementation of diet with CM lowered feed intake. Also, reduction of ADFI by $\mathrm{CM}$ inclusion may affect the ADG and G:F ratio in finishing period [22]. It is considered to be due to rancidity after prolonged storage [23] or the lower density and more swelling (high crude fiber) of CM [18].

This result demonstrated that palatability was affected by level of $20 \% \mathrm{CM}$ in finishing phase. However, ADFI in growing phase was not affected, and there was an improvement of feed efficiency by increasing level of $\mathrm{CM}$ in early growing phase. These observations were supported by the result of former researchers [22, 23].

Consequently, during the whole experimental period, there were no significant differences in growth performance when fed up to $25 \%$ of CM with $0.10 \%$ of $\beta$ mannanase.

\section{Blood profiles}

Blood profiles parameters during feeding trial were presented in Figs. 1, 2 and 3. During the whole experimental period, there was no significant difference in glucose concentration when pigs were fed diet with increasing level of CM. Mannans and galactomannans in CM might reduce the absorption of glucose and decrease the production of insulin [17, 24]. But, Kim et al. [25], demonstrated that the concentration of blood glucose in pigs fed diet with $\beta$-mannanase was greater than pigs fed diet without $\beta$-mannanase $(P=0.03)$. The result of this study was considered as due to the reduced negative effects of anti-nutritional factor by added dietary $\beta$-mannanase [26]. At 6 week, linear increasing of BUN was observed as CM supplementation level increased (linear, $P=0.02$ ). The BUN has been known to a good indicator for evaluation in protein quality, protein intake [27] and nitrogen retention [28] by pigs. Münchow and Bergner [29] reported that there was a highly negative correlation between the biological value of feed and BUN content. Increase of BUN concentration indicated that excessive amino acids are inefficiently metabolized and circulated in the blood before excretion [30, 31]. Although a linear response by $\mathrm{CM}$ supplementation level was observed at 6 week, the BUN value of all treatments were in normal range $(10.0-30.0 \mathrm{mg} / \mathrm{dL})$. Consequently, $\mathrm{CM}$ inclusion with $\beta$-mannanase did not negatively affect the blood glucose and BUN.

\section{Nutrient digestibility}

The effect of $\mathrm{CM}$ supplementation with $\beta$-mannanase on nutrient digestibility was presented in Table 7 . The digestibility of crude protein in growing pigs was linearly declined with increasing inclusion of $\mathrm{CM}$ (linear, $P=$ $0.02)$, and the tendency of decrease was found when over $15 \%$ of $\mathrm{CM}$ was supplemented $(P=0.07)$. The digestibility of dry matter, crude fat, and crude ash showed no significant difference among treatments. Nitrogen retention tended to be decreased (linear, $P=0.08$ ) as $\mathrm{CM}$ level increased in pig diet, leading to the tendency of increasing in fecal nitrogen (linear, $P=0.05$ ).

During heating process of $\mathrm{CM}$, the Maillard reaction occurred between mannose and amino group which

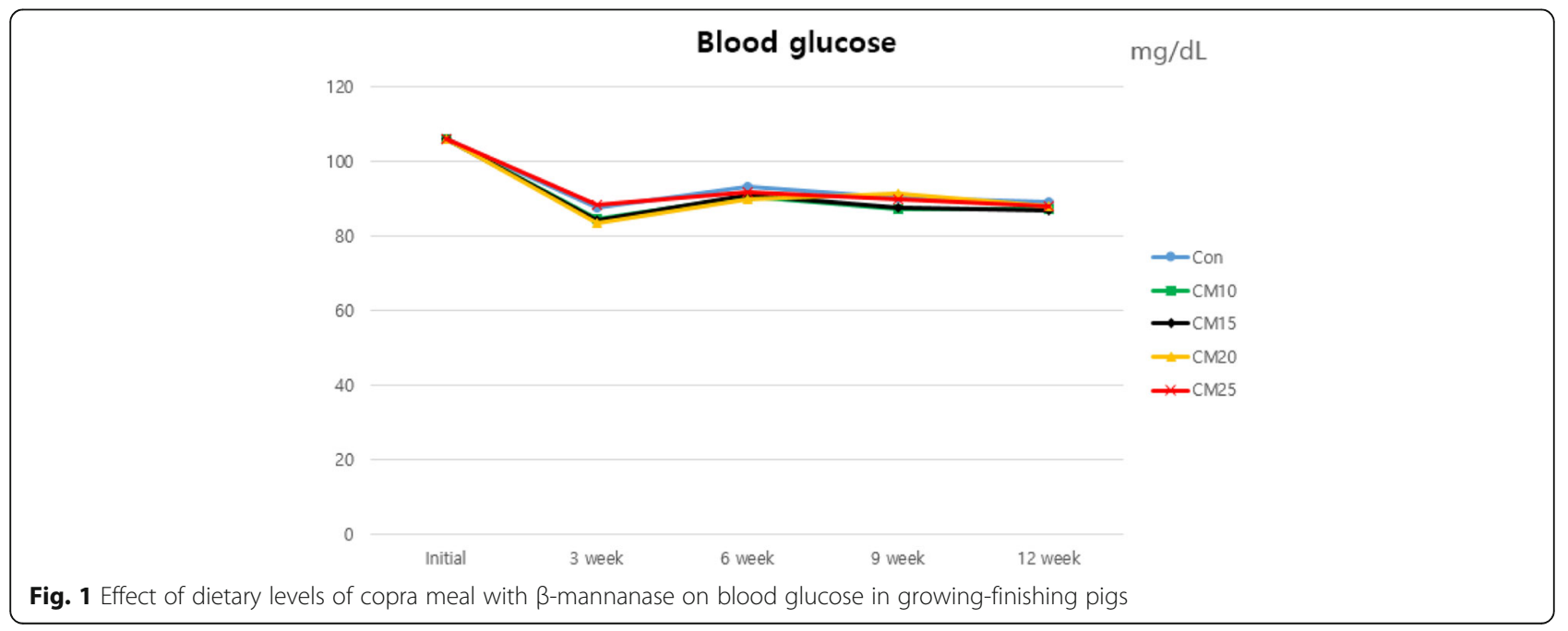




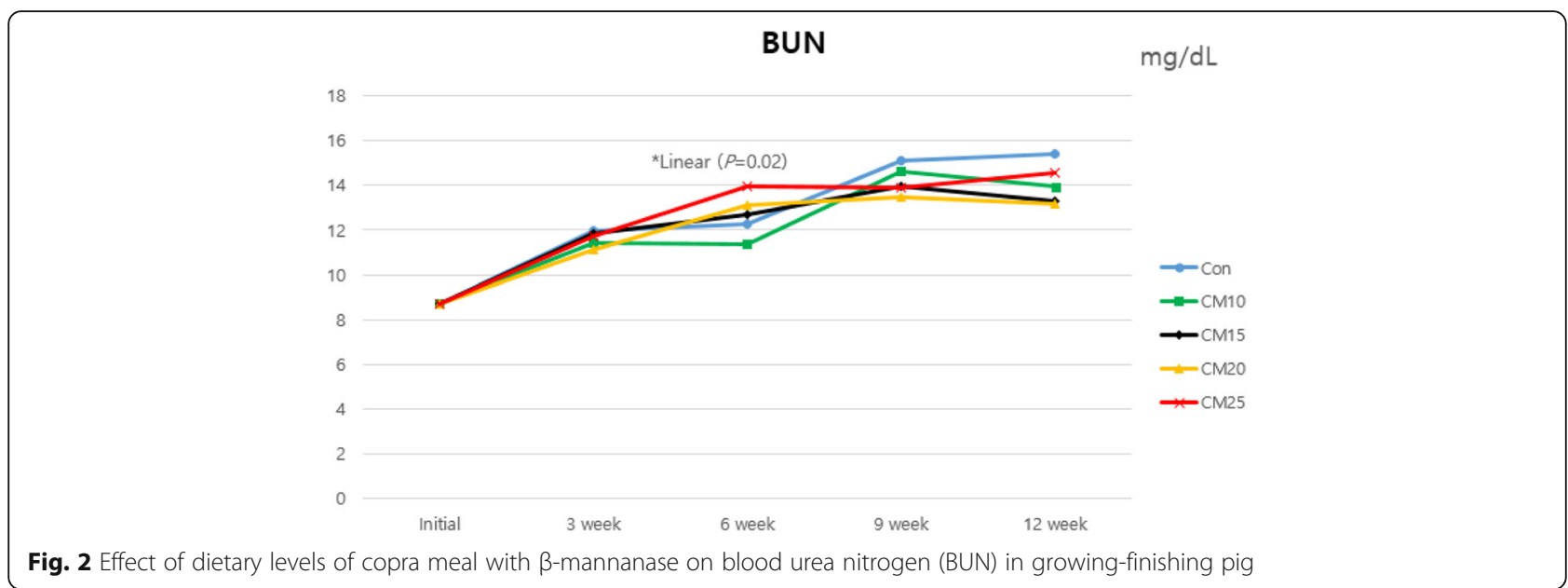

alleviated total nutritional value of CM [32]. Also, Kim et al. [3] demonstrated that lowered digestibility was observed when pigs were fed CM because of the higher crude fiber level in CM than in SBM. The negative effect of fiber might be from the effect of fiber on transit time, water-binding capacity of fiber, mechanical erosion and absorption of nutrients on the fiber [33].

Consequently, increasing level of CM caused lower crude protein $(\mathrm{CP})$ digestibility by higher fiber which was the reason of increased fecal nitrogen and reduced nitrogen retention.

\section{Carcass traits and pork quality}

The effect of CM supplementation with $\beta$-mannanase on $\mathrm{pH}$ of pork was presented in Fig. 3. In this study, increasing level of $\mathrm{CM}$ did not affect the $\mathrm{pH}$ levels change and the $\mathrm{pH}$ value at $0,24 \mathrm{~h}$.

The $\mathrm{pH}$ change of pork is a very important factor that determines the quality of pork and has an influence on freshness, tenderness, meat color and texture [34].

It is also an important factor for the storage [35]. In fact, the initial $\mathrm{pH}$ is regarded as an indication of PSE (pale, soft and exudative) pork and the final $\mathrm{pH}$ is acknowledged as an estimation of DFD (dark, firm and dry). In general, $\mathrm{pH}$ decline is accelerated as time goes by, and ultimate $\mathrm{pH}$ is reduced because of creation of lactic acid from glycogen [36-38]. In this study, since the $\mathrm{CM}$ level in diet did not affect $\mathrm{pH}$ of pork, it is considered that inclusion of $\mathrm{CM}$ did not have adverse effect on pork quality which was correlated with $\mathrm{pH}$.

The results of pork color were presented in Table 8 . There was no significant difference among treatments in $L^{*}, a^{*}$ and $b^{*}$ value at $0,3,6,9,12,24 \mathrm{~h}$ after slaughter. In pork color, decreasing in redness and increasing in yellowness had a negative influence on the freshness of pork [39]. But, there was no change in redness or yellowness by $\mathrm{CM}$ level in diet. These findings were in accordance with those of Hong [40], who had demonstrated that $a^{*}$ and $b^{*}$ values were not

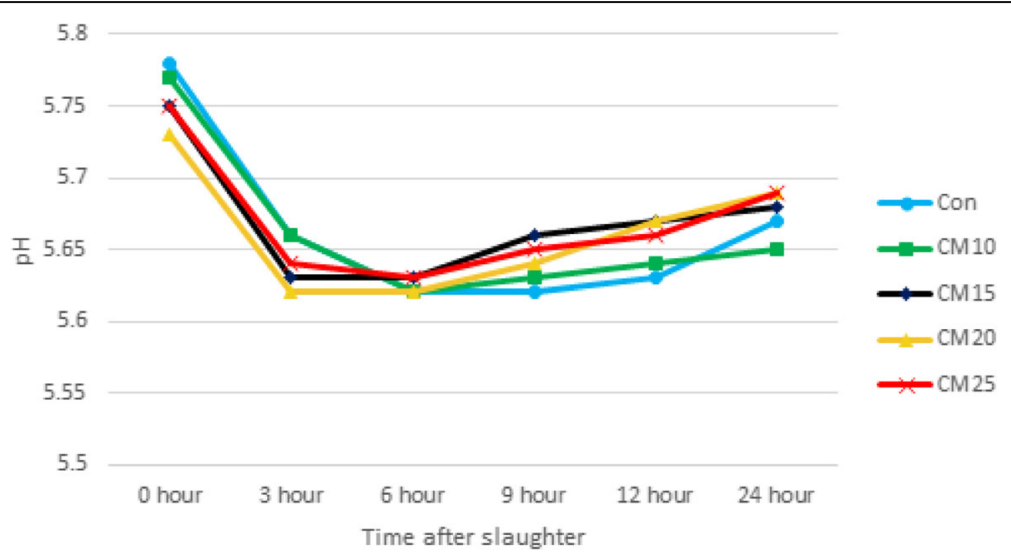

Fig. 3 Effect of dietary levels of copra meal with $\beta$-mannanase on $\mathrm{pH}$ at slaughtering 
Table 7 Effect of dietary levels of copra meal with $\beta$-mannanase on nutrient digestibility in growing pigs ${ }^{a}$

\begin{tabular}{|c|c|c|c|c|c|c|c|c|}
\hline \multirow[t]{2}{*}{ Criteria } & \multicolumn{5}{|c|}{ Treatment } & \multirow[t]{2}{*}{$\mathrm{SEM}^{\mathrm{b}}$} & \multicolumn{2}{|c|}{$P$-value } \\
\hline & Con & CM10 & CM15 & CM20 & CM25 & & Lin. & Quad. \\
\hline \multicolumn{9}{|c|}{ Nutrient digestibility (\%) } \\
\hline Dry matter & 85.69 & 86.79 & 83.65 & 84.60 & 85.82 & 0.433 & 0.39 & 0.12 \\
\hline Crude protein & 83.19 & 83.93 & 80.95 & 80.76 & 80.68 & 0.551 & 0.02 & 0.73 \\
\hline Crude fat & 56.71 & 58.13 & 56.35 & 55.82 & 58.32 & 0.976 & 0.49 & 0.63 \\
\hline Crude ash & 65.47 & 67.57 & 60.99 & 64.45 & 64.00 & 1.184 & 0.87 & 0.60 \\
\hline \multicolumn{9}{|c|}{ Nitrogen retention ${ }^{c}, \mathrm{~g} /$ day } \\
\hline N-intake & 16.60 & 16.74 & 16.70 & 16.58 & 16.49 & 0.186 & 0.75 & 0.71 \\
\hline $\mathrm{N}$-feces & 2.80 & 2.69 & 3.19 & 3.20 & 3.19 & 0.112 & 0.05 & 0.66 \\
\hline N-urine & 10.17 & 10.55 & 9.95 & 10.21 & 10.22 & 0.141 & 0.84 & 0.94 \\
\hline N-retention & 3.63 & 3.50 & 3.55 & 3.16 & 3.09 & 0.127 & 0.08 & 0.70 \\
\hline N-digestibility (\%) & 21.81 & 20.90 & 21.24 & 19.10 & 18.73 & 0.692 & 0.13 & 0.81 \\
\hline
\end{tabular}

${ }^{\mathrm{a}} \mathrm{A}$ total of 15 barrows with an initial body weight $34.7 \pm 0.24 \mathrm{~kg}$

${ }^{\mathrm{b}}$ Standard error of the mean

${ }^{\mathrm{c}} \mathrm{N}$ retention $=\mathrm{N}$ intake - Fecal $\mathrm{N}-$ Urinary $\mathrm{N}$

Table 8 Effect of dietary levels of copra meal with $\beta$-mannanase on pork color after slaughter

\begin{tabular}{|c|c|c|c|c|c|c|c|c|}
\hline \multirow[t]{2}{*}{ Criteria } & \multicolumn{5}{|c|}{ Treatment } & \multirow[t]{2}{*}{ SEM $^{a}$} & \multicolumn{2}{|c|}{$P$-value } \\
\hline & $\overline{C o n}$ & CM10 & CM15 & CM20 & CM25 & & Lin. & Quad. \\
\hline \multicolumn{9}{|c|}{$\overline{C I E}$ value ${ }^{\mathrm{b}}, \mathrm{L}^{*}$} \\
\hline $\mathrm{Oh}$ & 44.01 & 44.60 & 43.32 & 42.53 & 44.32 & 0.658 & 0.78 & 0.64 \\
\hline $3 \mathrm{~h}$ & 44.59 & 43.33 & 43.88 & 43.28 & 44.85 & 0.714 & 0.93 & 0.47 \\
\hline $6 \mathrm{~h}$ & 46.30 & 47.57 & 46.63 & 45.13 & 47.71 & 0.539 & 0.92 & 0.64 \\
\hline $9 \mathrm{~h}$ & 47.61 & 47.32 & 47.53 & 46.50 & 48.86 & 0.482 & 0.50 & 0.19 \\
\hline $12 \mathrm{~h}$ & 47.59 & 47.00 & 46.70 & 46.52 & 48.24 & 0.517 & 0.80 & 0.23 \\
\hline $24 \mathrm{~h}$ & 48.37 & 46.49 & 48.17 & 47.72 & 49.30 & 0.593 & 0.34 & 0.22 \\
\hline \multicolumn{9}{|c|}{ CIE value, $a^{*}$} \\
\hline $\mathrm{Oh}$ & 2.47 & 2.85 & 2.35 & 2.00 & 2.32 & 0.128 & 0.18 & 0.98 \\
\hline $3 \mathrm{~h}$ & 3.19 & 2.92 & 2.43 & 2.51 & 2.78 & 0.113 & 0.15 & 0.11 \\
\hline $6 \mathrm{~h}$ & 3.17 & 3.81 & 2.67 & 2.48 & 2.81 & 0.189 & 0.12 & 0.82 \\
\hline $9 \mathrm{~h}$ & 3.52 & 3.35 & 3.04 & 2.91 & 3.69 & 0.153 & 0.93 & 0.15 \\
\hline $12 \mathrm{~h}$ & 3.81 & 4.08 & 3.30 & 3.03 & 4.00 & 0.156 & 0.52 & 0.13 \\
\hline $24 \mathrm{~h}$ & 4.37 & 4.12 & 3.97 & 3.86 & 4.40 & 0.132 & 0.81 & 0.13 \\
\hline \multicolumn{9}{|c|}{ CIE value, $b^{*}$} \\
\hline $\mathrm{Oh}$ & 4.88 & 4.79 & 4.68 & 4.27 & 4.54 & 0.130 & 0.22 & 0.70 \\
\hline $3 \mathrm{~h}$ & 5.57 & 4.79 & 4.92 & 4.82 & 5.05 & 0.151 & 0.33 & 0.15 \\
\hline $6 \mathrm{~h}$ & 5.68 & 5.69 & 5.36 & 5.01 & 5.50 & 0.156 & 0.35 & 0.48 \\
\hline $9 \mathrm{~h}$ & 5.93 & 5.64 & 5.61 & 5.57 & 6.19 & 0.143 & 0.63 & 0.12 \\
\hline $12 \mathrm{~h}$ & 6.07 & 5.98 & 5.75 & 5.76 & 6.19 & 0.136 & 0.96 & 0.22 \\
\hline $24 \mathrm{~h}$ & 6.72 & 6.29 & 6.27 & 6.29 & 6.56 & 0.135 & 0.68 & 0.11 \\
\hline
\end{tabular}

atandard error of the mean

${ }^{\mathrm{b} C I E} \mathrm{~L}$ : luminance or brightness (vary from black to white), a: red · green component $(+\mathrm{a}=$ red,$-\mathrm{a}=$ green $)$, b: yellow $\cdot$ blue component $(+\mathrm{b}=$ yellow,$-\mathrm{b}=$ blue $)$ affected by $\mathrm{CM}$ inclusion level when $0.10 \%$ of $\beta$-mannanase supplemented.

The effects of on the carcass characteristics of growing-finishing pigs fed with increasing level of $\mathrm{CM}$ with $\beta$-mannanase were noted in Table 9. In current study, the level of CM did not affect the cooking loss, shear force, water holding capacity (WHC) and proximate analysis of the pork after slaughter. The result of fat content contrasted with those of Creswell and Brooks [2] who demonstrated that the relationship between dietary $\mathrm{CM}$ and fat composition of carcass and $\mathrm{CM}$ additions resulted in increased fatty acids in the backfat. When crude fat content increases in longissimus muscles, WHC is increased and shear force and cooking loss are decreased [41].

Table 9 Effect of dietary levels of copra meal with $\beta$-mannanase on pork quality

\begin{tabular}{|c|c|c|c|c|c|c|c|c|}
\hline \multirow[t]{2}{*}{ Criteria } & \multicolumn{5}{|c|}{ Treatment } & \multirow[t]{2}{*}{$\mathrm{SEM}^{a}$} & \multicolumn{2}{|c|}{$P$-value } \\
\hline & Con & CM10 & CM15 & $\mathrm{CM} 20$ & CM25 & & Lin. & Quad \\
\hline \multicolumn{9}{|c|}{ Proximate analysis, $\%$} \\
\hline Moisture & 66.10 & 65.52 & 65.34 & 66.01 & 65.26 & 0.142 & 0.23 & 0.65 \\
\hline $\begin{array}{l}\text { Crude } \\
\text { protein }\end{array}$ & 22.62 & 22.82 & 22.22 & 23.11 & 22.97 & 0.150 & 0.31 & 0.48 \\
\hline Crude fat & 1.72 & 1.76 & 1.69 & 1.61 & 1.62 & 0.093 & 0.64 & 0.93 \\
\hline Crude ash & 9.94 & 9.97 & 9.94 & 10.14 & 10.15 & 0.082 & 0.41 & 0.80 \\
\hline \multicolumn{9}{|c|}{ Physiochemical property } \\
\hline $\begin{array}{l}\text { Cooking } \\
\text { loss, } \%\end{array}$ & 32.07 & 30.99 & 33.13 & 31.34 & 33.18 & 0.334 & 0.24 & 0.45 \\
\hline Shear force ${ }^{b}$ & 3.32 & 3.27 & 3.40 & 3.01 & 3.36 & 0.086 & 0.78 & 0.73 \\
\hline WHC, \% & 56.74 & 55.67 & 55.01 & 55.14 & 54.93 & 0.322 & 0.11 & 0.39 \\
\hline
\end{tabular}

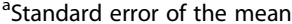

${ }^{\mathrm{b}} \mathrm{kg} / 0.5$ in 
Table 10 Effect of dietary levels of copra meal with $\beta$-mannanase on economic analysis

\begin{tabular}{|c|c|c|c|c|c|c|c|c|}
\hline \multirow[t]{2}{*}{ Criteria } & \multicolumn{5}{|c|}{ Treatment $^{a}$} & \multirow[t]{2}{*}{$\mathrm{SEM}^{\mathrm{a}}$} & \multicolumn{2}{|c|}{$P$-value } \\
\hline & Con & CM10 & CM15 & CM20 & CM25 & & Lin. & Quad. \\
\hline \multicolumn{9}{|c|}{ Feed cost per weight gain, won/kg } \\
\hline 0-3 week & 1,230 & 1,386 & 1,142 & 1,063 & 1,041 & 51.7 & 0.06 & 0.64 \\
\hline 4-6 week & 954 & 1,028 & 977 & 875 & 900 & 21.0 & 0.09 & 0.40 \\
\hline 7-9 week & 1,123 & 1,185 & 1,110 & 1,136 & 1,184 & 17.1 & 0.56 & 0.63 \\
\hline 10-12 week & 1,246 & 1,081 & 1,211 & 1,260 & 1,122 & 27.4 & 0.61 & 0.89 \\
\hline Total & 4,553 & 4,679 & 4,440 & 4,334 & 4,245 & 58.8 & 0.02 & 0.49 \\
\hline \multicolumn{9}{|c|}{ Total feed cost per pig, won/head } \\
\hline 0-3 week & 13,379 & 12,388 & 11,977 & 11,998 & 11,292 & 293.5 & 0.03 & 0.64 \\
\hline 4-6 week & 17,646 & 17,059 & 17,289 & 17,228 & 16,570 & 374.1 & 0.45 & 0.89 \\
\hline 7-9 week & 24,517 & 25,029 & 23,845 & 23,594 & 24,041 & 300.5 & 0.29 & 0.76 \\
\hline 10-12 week & 42,491 & 42,736 & 41,083 & 41,222 & 39,700 & $1,688.5$ & 0.48 & 0.89 \\
\hline Total & 98,033 & 97,212 & 94,194 & 94,042 & 91,603 & $1,245.8$ & 0.04 & 0.95 \\
\hline Relative ratio to control & 100.00 & 99.16 & 96.08 & 95.93 & 93.44 & - & - & - \\
\hline \multicolumn{9}{|c|}{ Days to market weight (reached at $115 \mathrm{~kg} \mathrm{BW)}$} \\
\hline & 101.1 & 101.7 & 101.9 & 104.0 & 104.0 & 1.50 & 0.46 & 0.95 \\
\hline
\end{tabular}

${ }^{\text {a }}$ Standard error of the mean

\section{Economic analysis}

The effects of dietary CM levels with $0.10 \%$ of $\beta$ mannanase on feed cost were presented in Table 10. There was a tendency in feed cost per weight gain in growing I phase (linear, $P=0.06$ ), growing II phase (linear, $P=0.09$ ). During overall period, there was decreasing in (linear, $P=0.02$ ) feed cost per weight gain according to effect of dietary CM levels increasing, either. Also, total feed cost per pig was reduced by dietary CM levels in growing I phase (linear, $P=0.03$ ) and during overall period (linear, $P=0.04$ ). Decreasing feed cost of high content of CM was mainly caused by the replacement of SBM. There was no significant response in days to market weight. Total feed cost in whole days to market weight was reduced up to $6.56 \%$ when fed diets with increasing level of CM. Also, feed cost (won $/ \mathrm{kg}$ ) reduction of 1.01 won was observed when each 1\% CM inclusion level increased.

\section{Conclusion}

In conclusion, there is a possibility for $\mathrm{CM}$ as an alternative feed ingredient in growing to finishing pigs up to $25 \%$. In growth performance, there was no detrimental effects in $25 \%$ of $\mathrm{CM}$ treatment with $0.10 \%$ of $\beta$-mannanase. Concentration of glucose and BUN showed general levels but linear increase of BUN was found as CM level increased. Pork quality was not affected by CM supplementation level. Although nutritional digestibility was linearly decreased as CM content increased, economic efficiency was linearly improved during the whole experimental period.
Consequently, CM as an alternative feed stuff could be supplemented in growing to finishing pig diets up to $25 \%$ when $\beta$-mannanase was supplemented.

\section{Abbreviations}

ADFI: Average daily feed intake; ADG: Average daily gain; BUN: Blood urea nitrogen; BW: Body weight; CM: Copra meal; CP: Crude protein;

CRD: Completely randomized design; DM: Dry matter; G:F ratio: Gain to feed ratio; GLM: General linear model; NSP: Non-starch polysaccharide; PKM: Palm kernel meal; RCB: Randomized complete block; SBM: Soy bean meal; WHC: Water holding capacity

\section{Acknowledgement}

This work was supported by Korea Institute of Planning and Evaluation for Technology in Food, Agriculture, Forestry and Fisheries (IPET) through Advanced Production Technology Development Program, funded by Ministry of Agriculture, Food and Rural Affairs (MAFRA).

\section{Funding}

This work was supported by Korea Institute of Planning and Evaluation for Technology in Food, Agriculture, Forestry and Fisheries (IPET) through Agri-Bio industry Technology Development Program, funded by Ministry of Agriculture, Food and Rural Affairs (MAFRA)

\section{Availability of data and materials}

Authors approved the data and materials availability.

\section{Authors' contributions}

HJK was mainly carried out this study and drafted the manuscript. JHJ, LHF, $\mathrm{HBY}$, and SHY were participated in the feeding trial, digestibility trial and blood sampling, together. SON and JSH were performed the statistical analysis and discussed the results. SWS and SHH were discussed the results. YYK conceived of the study, and participated in its design and coordination and helped to draft the manuscript. All authors read and approved the final manuscript.

\section{Ethics approval}

All experimental procedures involving animals were conducted in accordance with the Animal Experimental Guidelines provided by the Seoul National University Institutional Animal Care and Use Committee (SNU-

IACUC; SNU-160613-10). 


\section{Consent for publication}

Not applicable.

\section{Competing interests}

The authors declare that they have no competing interest.

\section{Publisher's Note}

Springer Nature remains neutral with regard to jurisdictional claims in published maps and institutional affiliations.

\section{Author details}

'Department of Agricultural Biotechnology, College of Agriculture and Life Sciences, Seoul National University, 1 Gwanak-ro, Gwanak-gu, Seoul 08826, Republic of Korea. ${ }^{2}$ PuKyung Pig Farmers Agricultural Cooperative, Gimhae 50925, Republic of Korea.

\section{Received: 29 January 2017 Accepted: 19 June 2017}

\section{Published online: 14 July 2017}

\section{References}

1. Agunbide JA, Wiseman J, Cole DJA. Energy and nutrient use of palm kernels, palm kernel meal and palm kernel oil in diets for growing pigs. Anim Feed Sci Technol. 1999:80:165-81.

2. Creswell DC, Brooks CC. Compositions, apparent digestibility and energy evaluation of coconut oil and coconut meal. J Anim Sci. 1971:33:366-9.

3. Kim BG, Lee HH, Jung HJ, Han YK, Park KM, Han IK. Effect of partial replacement of soybean meal with palm kernel meal and copra meal on growth performance, nutritional digestibility and carcass characteristics of finishing pigs. Asian Aust J Anim Sci. 2001;14:821-30.

4. Biavatti MW, Bellaver MH, Volpato L, Costa C, Bellaver C. Preliminary studies of alternative feed additives for broilers: Alternanthera brasiliana extract, propolis extract and linseed oil. J Poult Sci. 2003;5:147-51.

5. O' Doherty JV, McKeon MP. The use of expeller copra meal in grower and finisher pig diets. Livest Prod Sci. 2000;67:55-65.

6. Dung NNX, Manh LH, Uden P. Tropical fiber sources for pigs-digestibility, digesta retention and estimation of fibre digestibility in vitro. Anim Feed Sci Technol. 2002;102:109-24.

7. Sauvant D, Perez JM, Tran G. Tables of composition and nutritional value of feed materials. 2nd ed. Marijkeweg: Wageningen Academic Publishers; 2004.

8. Knudsen KEB. Carbohydrate and lignin contents of plant materials used in animal feeding. Anim Feed Sci Technol. 1997;67:319-38.

9. Saittagaroon S, Kawakishi S, Namiki M. Characterrization of polysaccharides of copra meal. J Sci Food Agri. 1983;34:855-60.

10. Dhawan S, Kaur J. Microbial mannanases: an overview of production and application. Crit Rev Biotechnol. 2007:27:197-216.

11. Hossain MZ, Abe J, Hizukuri S. Multiple forms of $\beta$-mannanase from Bacillus sp. KK01. Enzyme Microb Technol. 1996:18:95-8.

12. Lee $\mathrm{JH}$. Effects of mannose on growth performance, intestinal flora and nutrient digestibility in growing-finishing pigs, MS thesis. Seoul: Seoul National University; 2006.

13. NRC. Nutrient requirements of swine. 10th ed. Washington, D.C.: National Academy Press; 1998.

14. Hong JS, Lee Gl, Jin XH, Kim YY. Effect of dietary energy levels and phase feeding by protein levels on growth performance, blood profiles and carcass characteristics in growing-finishing pigs. J Anim Sci Technol. 2016; 58:37-46.

15. AOAC. Official Methods of Analysis. 16th ed. Arlington: Association of Official Analytical Chemists; 1995.

16. Statistical Analysis Systems Institute. SAS user'guide: statistics. version 9.4 2nd ed. Cary: SAS Institute Inc; 2013.

17. Nunes CS, Malmlof K. Effects of guar gum and cellulose on glucose absorption, hormonal release, and hepatic metabolism in the pig. Brit J Nutr. 1992:68:693-700.

18. Khanongnuch C, Sa-nguansook C, Lumyong S. Nutritive quality of mannanase treated copra meal in broiler diets and effectiveness on some fecal bacteria. Int J Poult Sci. 2006;5:1087-91.

19. Petty LA, Carter SD, Senne BW, Shriver JA. Effects of beta-mannanase addition to corn-soybean meal diets on growth performance, carcass traits, and nutrient digestibility of weaning and growing-finishing pig. J Anim Sci. 2002;80:1012-9.
20. Hahn JD, Gahl MJ, Giesemann MA, Holsgraefe DP, Fodge DW. Diet type and feed form effects on the performance of finishing swine fed the $\beta$ mannanase enzyme product Hemicell ${ }^{\oplus}$. J Anim Sci. 1995;73:175.

21. Jo JK, Ingale SL, Kim JS, Kim YW, Kim KH, Lohakare JD, Lee JH, Chae BJ. Effects of exogenous enzyme supplementation to corn and soybean mealbased or complex diets on growth performance, nutrient digestibility, and blood metabolites in growing pigs. J Anim Sci. 2012;90:3041-8.

22. Jaworski NW, Shoulders J, Gonzalez-Vega JC, Stein HH. Effects of using copra meal, palm kernel meal in diets in diets in diets for weanling pigs. Prof Anim Sci. 2014;30:243-51.

23. Ehrlich WK, Upton PC, Cowan RT, Moss RJ. Copra meal as a supplement for grazing dairy cows. Proc Aust Soc Anim Prod. 1990;18:196-9.

24. Rainbird AL, Low AG, Zebrowska T. Effect of guar gum on glucose and water absorption from isolated loops of jejunum in conscious growing pigs. Brit J Nutr. 1984;52:489-98.

25. Kim JS, Ingale SL, Lee SH, Kim KH, Kim JS, Lee JH, Chae BJ. Effects of energy levels of diet and $\beta$-mannananse supplementation on growth performance, apparent total tract digestibility and blood metabolites in growing pigs. Anim Feed Sci Technol. 2013;186:64-70.

26. Yoon SY, Yang YX, Shinde PL, Choi JY, Kim JS, Kim YW, Yun K, Jo JK, Lee JH, Ohh SJ, Kwon IK, Chae BJ. Effects of mannanase and distillers dried grain with soluble on growth performance, nutrient digestibility, and carcass characteristics of grower-finisher pigs. J Anim Sci. 2010;88:181-91.

27. Eggum BO. Blood urea measurement as a technique for assessing protein quality. Brit J Nutr. 1970;24:983-8.

28. Whang KY, Easter RA. Blood urea nitrogen as an index of feed efficiency and lean growth potential in growing-finishing swine. Asian Aust J Anim Sci. 2000;13:811-6.

29. Münchow $H$, Bergner $H$. Examination of techniques for protein evaluation of feedstuffs. Archiv Fur Tierenahrung. 1968;17:141-50.

30. Han IK, Lee JH, Piao XS, Defa L. Feeding and management system to reduce environmental pollution in swine production - review. Asian Aust J Anim Sci. 2001:14:432-44.

31. Jeong TS, Heo PS, Lee GY, Kim DH, Ju WS, Kim YY. The influence of phase feeding methods on growth performance, meat quality, and production cost in growing-finishing pigs. J Anim Sci Technol. 2001;52:29-36.

32. Butterworth $\mathrm{MH}$, Fox AC. The effect of heat treatment on the nutritice value of coconut meal and the prediction of the nutritive value by chemical methods. Brit J Nutr. 1963;17:445-52.

33. Nongyao A, Han IK, Choi YJ, Lee NH. Amino acid digestibility as affected by various fiber sources and levels. 1. Difference between ileal and fecal digestibility of amino acids. Asian Aust J Anim Sci. 1990:3:347-51.

34. Kauffman RG, Cassens RG, Scherer A, Meeker DL. Variations in pork quality. DesMoines: National Pork Producer Council; 1992

35. Huff-Lonergan EJ, Baas TJ, Malek M, Dekkers J, Prusa KJ, Rothschild MF. Correlations among selected pork quality traits. J Anim Sci. 2002;80:617-27.

36. Bee G, Biolley C, Guex G, Herzog W, Lonergan SM, Huff-Lonergan E. Effects of available dietary carbohydrate and preslaughter treatment on glycolytic potential, protein degradation, and quality traits of pig muscles. J Anim Sci. 2006:84:191-203.

37. Leheska D, Wulf M, Maddock RJ. Effects of fasting and transportation on pork quality development and extent of postmortem metabolism. J Anim Sci. 2002:80:3194-202.

38. Tikk K, Tikk M, Karlsson AH, Andersen HJ. The significance of a muscle glycogen reducing diet on porcine meat and fat color. 51st International Congress of Meat Sci and Technol. 2005;15:15-30.

39. Bendall JR, Wismer-Pedersen J. Some properties of the fibrillar proteins of normal and watery pork muscle. J Food Sci. 1962;27:144-59.

40. Hong YG. Different levels of copra meal supplementation with mannanase on growth performance, pork quality and nutrient digestibility in growing-finishing pigs, Thesis. Seoul: Seoul National University; 2009.

41. Goerl KF, Eilert SJ, Mandigo RW, Chen HY, Miller PS. Pork characteristics as affected by two populations of swine and six crude protein levels. J Anim Sci. 1995:73:3621-6. 